\title{
Controlled-Release Fertilizer in the Production of Seedlings of Anonna cacans Warm
}

\author{
Oscar José Smiderle \\ Brazilian Agricultural Research Corporation Embrapa Roraima \\ Rodovia BR 174, KM 8, Distrito Industrial, 69301-970, Boa Vista, RR, Brazil. \\ E-mail:oscar.smiderle@embrapa.br
}

\begin{abstract}
Aline das Graças Souza
Federal University of Paraíba, Department of Fitotecnia and Environmental Sciences Rodovia BR 079, Km 12,Campus II, 58.397-000, Areia, PB, Brazil.

E-mail:alineufla@hotmail.com

Renata Diane Menegatti (Corresponding Author)

Federal University of Pelotas, UFPel, Institute of Biology, Department of Botany Campus Universitário, S/N., Caixa Postal 345, 96010-900, Capão do Leão, RS, Brazil.

E-mail: renata.d.menegatti@gmail.com
\end{abstract}

Received: Jan. 1, 2020

doi:10.5296/jas.v8i3.16163
Accepted: Feb. 6, 2020

Published: Feb. 11, 2020

URL: https://doi.org/10.5296/jas.v8i3.16163

\begin{abstract}
The use of controlled-release fertilizers is a promising alternative for supplying nutrients during the initial growth of nursery seedlings. The aim of this study was to verify the effects of different doses of controlled-release fertilizer (CRF) on initial growth and nutritional status in seedlings of Anonna cacans Warm. The seeds were originally sown in a seedbed and then, after initial seedling development, were transplanted into polyethylene bags containing a substrate of washed medium sand, to which different doses of CRF had been added before transplanting. The experimental design was completely randomised, with four treatments, five doses of Osmocote ${ }^{\circledR}$ NPK 19-06-10 formulation (0, 1, 2, 4 and $8 \mathrm{~g} \mathrm{~L}^{-1}$ of substrate), with four replications, each replication comprising three seedlings (one in each container).
\end{abstract}


Increases in root-collar diameter and plant height were determined throughout the experimental period ( 6 months) from data collected every 30 days after transplanting. At the end of the experiment the following were evaluated: height, root-collar diameter, $\mathrm{N}$ concentration, chlorophyll index, chlorophyll concentration ( $\mathrm{a}, \mathrm{b}$ and total) and leaf area. Root-collar diameter and height showed a positive linear response to increases in the fertilizer dose. From a $4 \mathrm{~g} \mathrm{~L}^{-1}$ dose of CRF, the nutrient supply added to the substrate of medium sand optimises the initial phase of plant growth and guarantees the adequate nutritional status of Anonna cacans, and can be suggested as a viable technique for use in forest nurseries, and one which results in efficient use of the input material and avoids fertilizer wastage.

Keywords: araticum-cagão, photosynthetic pigments, plant nutrition, Osmocote ${ }^{\circledR}$

\section{Introduction}

Anonna cacans Warm, known locally as araticum-cagão, is a native forest species belonging to the family Annonaceae. It is classified as a pioneer and is recommended for recovery programs in degraded areas (Carvalho, 2010).

Its importance in the process of natural succession is based on the ability of the species to produce tasty fruit that are extremely attractive to the fauna which aid in dispersing the seeds and, due to their recurrent visits, favour acceleration of the process of ecological recovery and succession (Lorenzi, 2008). However, the seeds show a high degree of dormancy, a fact that limits their germination and the natural propagation process of the species (Dalanhol et al., 2013), and makes the production of seedlings, which are later used in recovery programs for degraded areas, indispensable to the process.

An improvement has recently been seen in the methods of seedling production in forest species, from promoting cultivation in protected environments, to the use of substrates and containers, and the use of fertilizers, all with the aim of accelerating plant growth and at the same time achieving superior characteristics of vigour, resistance, robustness and nutrition (Souza Júnior and Brancalion, 2016). These characteristics may guarantee greater success in the initial establishment of the plants in the field, even in the face of adverse conditions, fostering successful recovery programs in degraded areas (Gonçalves and Benedetti, 2005).

Although substrates available on the market are chemically, physically and biologically suitable for satisfactory plant growth, the use of fertilizers in doses appropriate to the species is suggested in order to guarantee maximum efficiency in the use of the supplied nutrients (Dutra et al., 2016) and lower the environmental and economic impact, especially in relation to nitrogen economy, a high cost element which is easily leachable and has the potential to pollute the rivers.

Commercially, numerous types of fertilizer are available. These vary in composition, type (powder, granules and coated) and solubility (Gonçalves and Benedetti, 2005; Epstein and Bloom, 2006), and have different advantages and disadvantages, including the need to reapply the fertilizer, i.e. top dressing, throughout the time the seedlings remain in the nursery until they are suitable for the market (Melo Júnior et al., 2014). 
The use of controlled-release fertilizers has proved to be a promising alternative for producing seedlings in protected environments, since they are only added when the substrate is prepared. The fertilizer being coated allows the nutrients to be released slowly through the porous structures and made available to the plant root system over time and according to nutritional requirements, minimising the risks of deficiency, and eventually resulting in better quality seedlings (Melo Júnior et al., 2014; Dutra et al., 2016; Menegatti et al., 2017a; Muniz et al., 2013).

In addition, controlled-release fertilizers are interesting alternatives, as they can reduce the time needed to obtain suitable seedlings for the market, shortening the production cycle, reducing manpower and mainly offering effective measures to be implemented by nurseries to improve seedling quality and optimize production costs (Azeem et al., 2014; Wang et al., 2016).

Considering the above, the aim of this study was to verify the effects of different doses of controlled-release fertilizer (CRF) on initial growth and physiological quality in seedlings of Anonna cacans Warm.

\section{Material and Methods}

Ripe fruit of Annona cacans Warm. were collected in the district of Rorainópolis in the state of Roraima, and taken to the seed laboratory of Embrapa Roraima, located in the town of Boa Vista.

The fruit was first pulped to remove the seeds, which were then washed in running water until the residue was completely removed, and kept at room temperature. The propagating material was later sown in a seedbed containing a substrate of washed sand for seedling germination and initial development. Substrate moisture was maintained by manual irrigation, watering four times a day.

Approximately thirty days after sowing, the seedlings began to emerge; once they had all reached a height of approximately $12.0 \mathrm{~cm}$, they were transplanted into polyethylene bags (15 x $35 \mathrm{~cm}$ ) containing a substrate of washed, medium sand (Table 1) to which doses of coated controlled-release NPK 19-06-10 formulation fertilizer (Osmocote ${ }^{\circledR}$ ) were added on the surface according to the treatments. The plants were then placed in the nursery under $50 \%$ shade, and irrigated by sprinkler for five minutes, three times a day.

Table 1. Chemical composition of the medium sand substrate used in the production of seedlings of Annona cacans Warm

\begin{tabular}{ccccccccccccccc}
\hline Substrate & $\mathrm{OM}$ & $\mathrm{V}$ & $\mathrm{Al}$ & $\mathrm{H}+\mathrm{Al}$ & $\mathrm{SB}$ & $\mathrm{CTC}$ & $\mathrm{P}$ & $\mathrm{K}$ & $\mathrm{Ca}$ & $\mathrm{Mg}$ & $\mathrm{Zn}$ & $\mathrm{Fe}$ & $\mathrm{Mn}$ \\
\hline & $\%$ & & $\mathrm{cmol}_{\mathrm{c}}$ & $\mathrm{dm}^{-3}$ & & & $\mathrm{mg} \mathrm{dm}$ & & & \multicolumn{2}{c}{$\mu \mathrm{dm}^{-3}$} \\
\hline \multirow{2}{*}{ Sand } & 0.0 & 67.0 & 0.0 & 0.0 & 0.0 & 0.0 & 0.0 & 0.0 & 0.0 & 0.0 & 0.4 & 0.0 & 0.0 \\
\hline
\end{tabular}

**OM: Organic Matter; V: Base saturation; SB: Sum of Bases; CEC: Cation Exchange Capacity. 


\section{MlMacrothink}

Journal of Agricultural Studies

ISSN 2166-0379

2020, Vol. 8, No. 3

The experimental design was completely randomized, with five treatments representing the five doses of Osmocote ${ }^{\circledR}\left(0,1,2,4\right.$ and $6 \mathrm{~g} \mathrm{~L}^{-1}$ of substrate), with five replications, each replication comprising three seedlings (one in each container).

The increases in height and root-collar diameter were determined from data collected every 30 days (month), from transplanting, throughout the period of plant growth, to the end of the experiment (six months). Plant height was measured with the aid of a graduated rule, and the root-collar diameter, with a digital caliper.

At 180 days (six months) after transplanting (DAT), when the experiment had ended, the chlorophyll index (CI) was determined using a chlorophyll meter (Dualex). Measurements were taken between 09:00 and 11:00 on two completely expanded leaves located on the apical third of each plant.

Immediately after taking the readings, the leaves were detached, placed in polystyrene boxes containing ice, and taken to the laboratory to determine the chlorophyll content. Leaf discs were removed from the samples, to make up a sample of approximately $1.5 \mathrm{~g}$ of fresh matter, which was macerated in $80 \%$ acetone in the absence of light. The resulting extracts were passed through filter paper and collected in $25 \mathrm{ml}$ volumetric flasks, and the volume topped up at the end of filtration. The supernatants were analyzed using an Agilent model UV-Vis spectrophotometer, from readings taken at $645 \mathrm{~nm}$ (A645) and $663 \mathrm{~nm}$ (A663) against a blank of $80 \%$ acetone. The chlorophyll a, chlorophyll b and total chlorophyll content were calculated using the equations established by Arnon (1949).

Four leaves were randomly detached per plant, numbered, and then used to determine the leaf area using the LI-COR $®$ model LI-3100 portable leaf area meter.

The leaves were later dried in a forced air circulation oven at $70^{\circ} \mathrm{C}$ for 72 hours to constant weight, and the individual weight of each leaf was determined using a precision balance. They were then ground in a Wiley mill equipped with a 20-mesh screen to determine the leaf-nitrogen concentration as per the methodology described by Malavolta et al. (1997).

Possible differences between treatments were verified by an analysis of variance of the data (ANOVA). All the variables were submitted to a comparison of mean values by Tukey's test at $5 \%$ probability, and the quantitative variables were submitted to regression analysis to verify the growth response of the plants over time. Data analysis was carried out using the Sisvar statistical software package (Ferreira, 2011).

\section{Results and Discussion}

The greatest mean values for height and root-collar diameter in plants of Annona cacans Warm. were obtained at the $8 \mathrm{~g} \mathrm{~L}^{-1}$ dose of CRF (Figure 1A and B), meeting the recommended and normalized standards for forest seedlings, which should have a diameter of $10 \mathrm{~mm}$ to $2 \mathrm{~cm}$ at the level of the root collar; a height of $60 \mathrm{~cm}$, measured from the root collar; and be aged from 4 to 7 months from planting (Smiderle and Souza, 2016). 

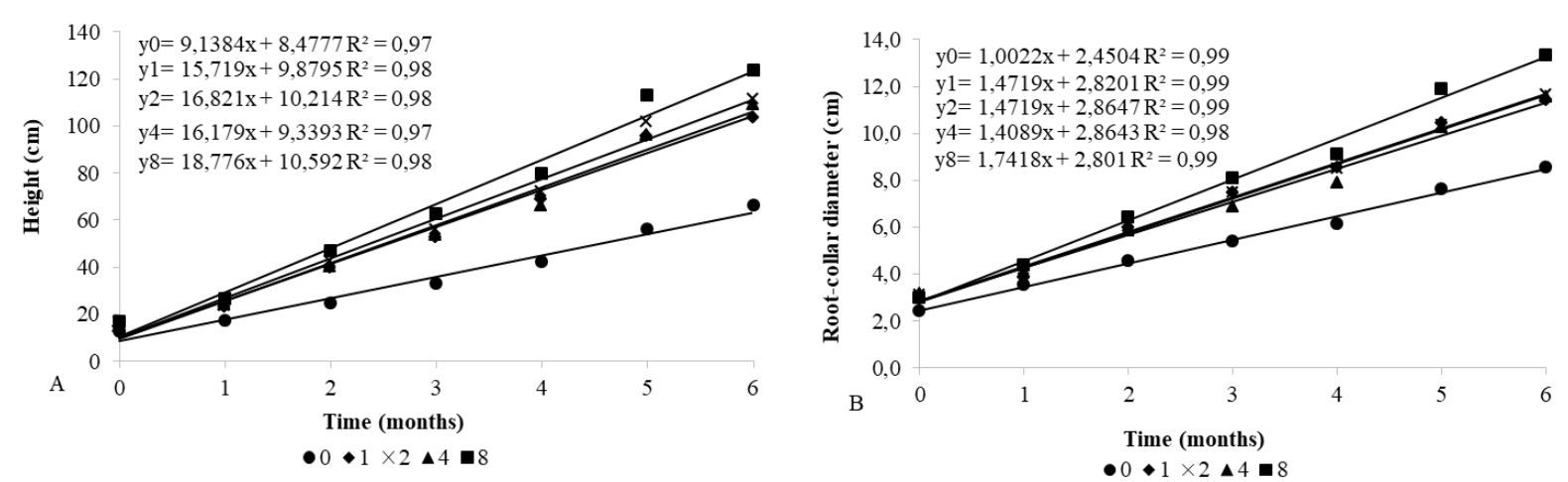

Figure 1. Height (A) and root-collar diameter (B) in plants of Anonna cacans Warm. grown for six months under $50 \%$ shade, for doses of controlled-release fertilizer (CRF)

The results also suggest that use of the highest dose of CRF under test was enough to supply the nutrient demand of the plants, allowing them to present increasing values, which were greater in comparison to those of the control treatment. Although there are no specific experiments for this species that might recommend the ideal plant size for use in recovery programs, the superiority of both variables is both sought and necessary to guarantee greater survival and growth in the seedlings after planting in the field.

Plants grown at the $8 \mathrm{~g} \mathrm{~L}^{-1}$ dose of CRF added to the substrate displayed early growth in height and root-collar diameter when compared to the other doses under test. This may be the result of the larger amount of available nutrients at the time of greatest nutrient need, both after transplanting and during plant growth, resulting in a reduction in the time the seedlings remain in the nursery, with a consequent reduction in production costs.

However, plants grown at the 1, 2 and $4 \mathrm{~g} \mathrm{~L}^{-1}$ doses of CRF added to the substrate achieved very similar responses for both variables during the six months of growth in the shaded nursery, as such, considering only the parameters of height and diameter, and taking into account the high cost of acquiring the CRF, the use of a smaller dose can make the application of CRF economically viable for use in forest nurseries. This is because, even with the cost of keeping these seedlings in the nursery for a longer period compared to the $8 \mathrm{~g} \mathrm{~L}^{-1}$ dose of CRF, the use of a smaller dose would result in fertilizer economy, making the unit cost per seedling more attractive due to the possibility of reducing expenses with this input.

For nitrogen concentration, the plants of Annona cacans Warm., grown at the 4 and $8 \mathrm{~g} \mathrm{~L}^{-1}$ doses of CRF added to the substrate, showed a higher concentration of this nutrient (Table 2). Nitrogen is considered an essential element for plants, as it is present in the composition of amino acids, amides, proteins, nucleic acids, coenzymes, chlorophylls and secondary metabolites, all directly or indirectly related to the biochemical and physiological processes which are indispensable to plant growth (Bassi et al., 2018). 
Table 2. Mean values for $\mathrm{N}$ concentration [N], chlorophyll index (CI), chlorophyll a (CHLa, $\mu \mathrm{g} / \mathrm{mL}$ ), chlorophyll b (CHLb, $\mu \mathrm{g} / \mathrm{mL}$ ), total chlorophyll (CHLT, $\mu \mathrm{g} / \mathrm{mL})$, and leaf area (LA) in plants of Annona cacans Warm. grown for six months under 50\% shade, for doses of controlled-release fertilizer (CRF)

\begin{tabular}{ccccccc}
\hline Treatment & {$[\mathrm{N}]$} & CI & CHL $a$ & CHL $b$ & CHLT & LA $\left(\mathrm{cm}^{3}\right)$ \\
\hline 0 & $8.82 \mathrm{c}$ & $18.12 \mathrm{c}$ & $26.22 \mathrm{c}$ & $9.31 \mathrm{c}$ & $19.27 \mathrm{c}$ & $61.95 \mathrm{c}$ \\
1 & $15.59 \mathrm{~b}$ & $43.32 \mathrm{~b}$ & $36.81 \mathrm{~b}$ & $9.96 \mathrm{~b}$ & $46.77 \mathrm{~b}$ & $105.00 \mathrm{~b}$ \\
2 & $16.31 \mathrm{~b}$ & $44.67 \mathrm{~b}$ & $37.21 \mathrm{~b}$ & $10.42 \mathrm{~b}$ & $47.65 \mathrm{~b}$ & $105.40 \mathrm{~b}$ \\
4 & $18.03 \mathrm{a}$ & $47.09 \mathrm{a}$ & $39.65 \mathrm{a}$ & $16.05 \mathrm{a}$ & $55.2 \mathrm{a}$ & $128.72 \mathrm{a}$ \\
8 & $21.02 \mathrm{a}$ & $55.48 \mathrm{a}$ & $40.66 \mathrm{a}$ & $17.91 \mathrm{a}$ & $58.58 \mathrm{a}$ & $129.43 \mathrm{a}$ \\
\hline $\mathrm{CV}(\%)$ & 7.09 & 6.80 & 4.47 & 15.55 & 3.92 & 11.79 \\
\hline
\end{tabular}

Mean values followed by the same letter in a column do not differ by Tukey's test ( $\mathrm{p} \leq 5 \%$ ).

Similar to the variable, $\mathrm{N}$ concentration, the chlorophyll index (CI) was higher in plants of Annona cacans Warm. grown at the 4 and $8 \mathrm{~g} \mathrm{~L}^{-1}$ doses of CRF added to the substrate. The same result was also found for the variables CHLa, CHLb and CHLT, and can be considered predictable, since supplying plants with higher doses of CRF promotes greater $\mathrm{N}$ uptake and concentration in the plants; as this nutrient is the substrate for chlorophyll synthesis, biosynthesis of the molecule was to be expected (Cartelat et al., 2005).

Conversely, plants of Annona cacans Warm. grown with $\mathrm{N}$, or at lower doses (1 and $\left.2 \mathrm{~g} \mathrm{~L}^{-1}\right)$ of CRF added to the substrate, displayed possible limitations in synthesising the chlorophyll molecule, shown by a reduction in concentrations of this molecule; this may have reduced the rates of carbon fixation, and resulted in the restricted production of carbohydrates that could serve as a substrate for the synthesis of new organic molecules, as well as for respiration.

With the reduction in carbohydrates, the respiratory process is compromised, and since respiration is mainly responsible for supplying energy for nutrient uptake and for maintaining the rates of plant growth, it therefore suggests that the supply of $\mathrm{N}$ from doses of less than $2 \mathrm{~g}$ $\mathrm{L}^{-1}$ would result in such disadvantages as inferior growth characteristics and inferior physiological and nutritional quality in the plants.

Higher values for leaf area were also obtained in plants of Annona cacans Warm. grown at the 4 and $8 \mathrm{~g} \mathrm{~L}^{-1}$ doses of CRF added to the substrate. Studies have shown that an increase in leaf area has a direct correlation with increases in the number of leaves per plant (Silva et al., 2011; Menegatti et al., 2017a), affording greater efficiency in photosynthetic carbon assimilation (Afonso et al., 2017). This in turn is directly related to the availability of energy for growth optimization during the initial phase of plant development.

According to Muniz et al. (2013) and Menegatti et al. (2017b), supplying nutrients at the fertilizer dose determined as ideal for a species results in a satisfactory increase in both RCD and $\mathrm{H}$, accelerating the growth process of the plants at the same time as obtaining seedlings 
with superior vigour, resistance and robustness. Furthermore, defining the ideal dose allows the input to be used efficiently, avoiding fertilizer wastage, thereby reducing production costs (Machado et al., 2011; Muniz et al., 2013).

However, in addition to the physiological, nutritional and growth characteristics displayed by the $\mathrm{N}$ concentration, the chlorophyll index (CI) and the variables CHLa, CHLb and CHLT, they should also be taken into consideration as they indicate the physiological and nutritional status of the plants, and demonstrate the probability of success in initially establishing the seedlings in the field. Moreover, obtaining quality seedlings is decisive for guaranteeing the competitiveness of the nursery and stability of the enterprise over time.

Positive and significant correlations were found between most of the variables under study (Table 3). A correlation of more than 0.70 between each variable and the $\mathrm{N}$ concentration shows that observation of such growth characteristics as H and RCD can be used to infer the physiological and nutritional quality of the plants, since this characteristic shows a correlation with the other variables. Furthermore, as it is not a destructive method, it is also operationally feasible.

Table 3. Pearson's correlation between the variables height $(\mathrm{H})$, root-collar diameter $(\mathrm{RCD})$, number of leaves (NL), chlorophyll index (CI), chlorophyll a (CHLa, $\mu \mathrm{g} / \mathrm{mL})$, chlorophyll b $(\mathrm{CHLb}, \mu \mathrm{g} / \mathrm{mL})$ and total chlorophyll (CHLT $\mu \mathrm{g} / \mathrm{mL}), \mathrm{N}$ concentration $(\mathrm{N})$ and leaf area standard method (LA)

\begin{tabular}{|c|c|c|c|c|c|c|c|c|c|}
\hline & $\mathrm{RCD}$ & NL & CI & CHLa & $\mathrm{CHL} b$ & CHLT & {$[\mathrm{N}]$} & LDW & LA \\
\hline $\mathrm{H}$ & $0.89 *$ & $0.85^{*}$ & $0.79 *$ & $0.88 *$ & $0.76^{*}$ & $0.80 *$ & $0.89 *$ & $0.82 *$ & $0.67 *$ \\
\hline $\mathrm{RCD}$ & & $0.79 *$ & $0.69 *$ & $0.67 *$ & $0.52 *$ & $0.57 *$ & $0,73^{*}$ & $0.74 *$ & $0.53^{*}$ \\
\hline NL & & & $0.86^{*}$ & $0.76^{*}$ & $0.91^{*}$ & $0.94 *$ & $0.91 *$ & $0.95^{*}$ & $0.84 *$ \\
\hline CI & & & & $0.71 *$ & $0.68^{*}$ & $0.91 *$ & $0.94 *$ & $0.82 *$ & $0.81^{*}$ \\
\hline CHLa & & & & & $0.75^{*}$ & $0.79 *$ & $0.81^{*}$ & $0.77 *$ & $0.70 *$ \\
\hline CHL $b$ & & & & & & $0.69 *$ & $0.70 *$ & $0.57 *$ & $0.61 *$ \\
\hline CHLT & & & & & & & $0.98^{*}$ & $0.90 *$ & $0.92 *$ \\
\hline$[\mathrm{N}]$ & & & & & & & & $0.91 *$ & $0.94 *$ \\
\hline LA & & & & & & & & & \\
\hline
\end{tabular}

Where: * significant at $1 \%$ probability

Considering that no information can be found concerning the physiological mechanisms of plants of Annona cacans Warm. in either the domestic or international literature, the present study makes an important contribution with information for guiding the nutritional management of plants of Annona cacans Warm. during the seedling-production stage. 


\section{Conclusion}

The supply of nutrients from the $4 \mathrm{~g} \mathrm{~L}^{-1}$ dose of CRF added to the substrate of medium sand optimizes the initial phase of plant growth and ensures adequate physiological and nutritional status in plants of Annona cacans Warm.

\section{Acknowledgement}

The authors would like to thank the CNPq and Embrapa Roraima (Brazil).

\section{References}

Afonso, M. V., Martinazzo, E. G., Aumonde, T. Z., \& Villela, F. A. (2017). Parâmetros fisiológicos de mudas de Albizia niopoides produzidas em diferentes composições de substrato. Ciência Florestal, 27, 1395-1402. https://doi.org/10.5902/1980509830221

Arnon, D. I. (1949). Copper enzymes in isolated chloroplasts. polyphenoloxidase in Beta Vulgaris. Plant physiology, 24, 1-15. https://doi.org/10.1104/pp.24.1.1

Azeem, B., Kushaari, K., Man, Z. B., Basit, A., \& Thanh, T. H. (2014). Review on materials $\&$ methods to produce controlled release coated urea fertilizer. Journal of Controlled Release, 181, 11-21. https://doi.org/10.1016/j.jconrel.2014.02.020

Bassi, D., Menossi, M., \& Mattiello, L. (2018). Nitrogen supply influences photosynthesis establishment along the sugarcane leaf. Scientific Reports, 8, 2327-2340. https://doi.org/10.1038/s41598-018-20653-1

Cartelat, A., Cerovic, Z. G., Goulas, Y., Meyer, S., Lelarge, C., Prioul, J. L., Barbottin, A., ... Moya, I. (2005). Optically assessed contents of leaf polyphenolics and chlorophyll as indicators of nitrogen deficiency in wheat (Triticum aestivum L.). Field Crops Research, 9, 35-49. https://doi.org/10.1016/j.fcr.2004.05.002

Carvalho, P. E. R. (2010). Espécies arbóreas brasileiras. Brasília: Embrapa Informação Tecnológica, 664.

Dalanhol, S. J., Mombach, T. C., Toderke, M. L., Nogueira, A. V., \& Bortolini, M. F. (2013). Dormência em sementes de Annona cacans Warm. (Annonaceae). Revista da acadêmia de Ciências Agrárias e Ambientais, 11, 183-189.

http://dx.doi.org/10.7213/academica.10.S01.AO21

Dutra, T. R., Massa, M. D., \& Sarmento, M. F. Q. (2016). Fertilizante de liberação lenta no crescimento e qualidade de mudas de canafístula (Peltophorum dubium). Revista Floresta, 46, 491-498. https://doi.org/10.5380/rf.v46i4.44570

Epstein, E., \& Bloom, A. J. (2006). Mineral nutrition of plants. Sunderland: Sinauer Associates, 468.

Ferreira, D. F. (2011). Sisvar: a computer statistical analysis system. Ciência Agrotecnologia, 35, 1039-1042. https://doi.org/10.1590/S1413-70542011000600001

Gonçalves, J. L. de M., \& Benedetti, V. (2005). Nutrição e fertilização florestal. Piracicaba : IPEF, 427p. 


\section{Macrothink}

Lorenzi, H. (2008). Árvores brasileiras: manual de identificação e cultivo de plantas arbóreas nativas do Brasil. $6^{\circ}$ ed. São Paulo, Instituto Plantarum, 640.

Machado, D. L. M., Lucena, C. C., Santos, D., Siqueira, D. L., Matarazzo, P. H. M., \& Struiving, T. B. (2011). Slow-release and organic fertilizers on early growth of Rangpur lime. Revista Ceres, 58, 359-365. https://doi.org/10.1590/S0034-737X2011000300017

Malavolta, E., Vitti, G. C., \& Oliveira, S. A. (1997). Avaliação do estado nutricional das plantas. Princípios e aplicações. $2^{\mathrm{a}}$ ed. Piracicaba: POTAFOS, 319.

Melo Júnior, J .C. F. de A., Lima, A. M. N., Teixeira, M. V., Conceição, G. C. da, \& Santos, L. R. das. (2014). Depleção de água no substrato e doses de fertilizante Osmocote ${ }^{\circledR}$ na formação de mudas de mamoeiro. Comunicata Scientiae, 5, 499-508.

https://doi.org/10.14295/cs.v5i4.1084

Menegatti, R. D., Guollo, K., Navroski, M. C., \& Vargas, O. F. (2017a). Fertilizante de liberação lenta no crescimento inicial de Aspidosperma parvifolium A. DC. Sciencia Agraria Paranaensis, 16, 45-49. http://dx.doi.org/10.18188/1983-1471/sap.v16n1p45-49

Menegatti, R. D., Navroski, M. C., Guollo, K., Fior, C. D., Souza, A. das G. de, \& Possenti, J. C. (2017b). Formação de mudas de guatambu em substrato com hidrogel e fertilizante de liberação controlada. Revista Espacios, 38, 35.

Muniz, C. O., Lôbo, L. M., Fernandes, F. P. R., Ferreira, E. M., \& Brasil, E. P. F. (2013). Efeito de diferentes adubos NPK no processo de produção de mudas de Eucalipto. Enciclopédia Biosfera, 9, 1162-1168.

Silva, E. A., Silva, B. M. da, Cogo, F. D., \& Oliveira, L. M. da. (2011). Produção de mudas de porta-enxerto de limão-cravo em tubetes sob diferentes substratos. Enciclopédia biosfera. 7, 847-855.

Smiderle, O. J., \& Souza, A. G. (2016). Production and quality of Cinnamomum zeylanicum Blume seedlings cultivated in nutrient solution. Revista Brasileira Ciências Agrárias, 2, 104-110. https://doi.org/10.5039/agraria.v11i2a5364

Souza Junior, C. N., \& Brancalion, P. H. S. (2016). Sementes e mudas: guia para propagação de árvores brasileiras. São Paulo: Oficina de Textos, 464.

Wang, P., Lombi, E., Zhao, F. J., \& Kopittke, P. M. (2016). Nanotechnology: A New Opportunity in Plant Sciences. Trends Plant Science, 21, 699-712.

https://doi.org/10.1016/j.tplants.2016.04.005

\section{Copyright Disclaimer}

Copyright for this article is retained by the author(s), with first publication rights granted to the journal.

This is an open-access article distributed under the terms and conditions of the Creative Commons Attribution license (http://creativecommons.org/licenses/by/4.0/). 